\title{
Front Matter: Volume 9957
}

, "Front Matter: Volume 9957," Proc. SPIE 9957, Wide Bandgap Power Devices and Applications, 995701 (23 December 2016); doi:

$10.1117 / 12.2256398$

SPIE Event: SPIE Optical Engineering + Applications, 2016, San Diego, California, SPIE. United States 


\title{
PROCEEDINGS OF SPIE
}

\section{Wide Bandgap Power Devices and Applications}

\author{
Mohammad Matin \\ Abdul A. S. Awwal \\ Achyut K. Dutta \\ Editors
}

29 August 2016

San Diego, California, United States

Sponsored and Published by

SPIE 
The papers in this volume were part of the technical conference cited on the cover and title page. Papers were selected and subject to review by the editors and conference program committee. Some conference presentations may not be available for publication. Additional papers and presentation recordings may be available online in the SPIE Digital Library at SPIEDigitallibrary.org.

The papers reflect the work and thoughts of the authors and are published herein as submitted. The publisher is not responsible for the validity of the information or for any outcomes resulting from reliance thereon.

Please use the following format to cite material from these Proceedings:

Author(s), "Title of Paper," in Wide Bandgap Power Devices and Applications, edited by Mohammad Matin, Abdul A. S. Awwal, Achyut K. Dutta, Proceedings of SPIE Vol. 9957 (SPIE, Bellingham, WA, 2016) Six-digit Article CID Number.

ISSN: 0277-786X

ISSN: 1996-756X (electronic)

ISBN: 9781510603059

ISBN: 9781510603066 (electronic)

Published by

SPIE

P.O. Box 10, Bellingham, Washington 98227-0010 USA

Telephone +1 3606763290 (Pacific Time) · Fax +1 3606471445

SPIE.org

Copyright @ 2016 , Society of Photo-Optical Instrumentation Engineers.

Copying of material in this book for internal or personal use, or for the internal or personal use of specific clients, beyond the fair use provisions granted by the U.S. Copyright Law is authorized by SPIE subject to payment of copying fees. The Transactional Reporting Service base fee for this volume is $\$ 18.00$ per article (or portion thereof), which should be paid directly to the Copyright Clearance Center (CCC), 222 Rosewood Drive, Danvers, MA 01923 . Payment may also be made electronically through CCC Online at copyright.com. Other copying for republication, resale, advertising or promotion, or any form of systematic or multiple reproduction of any material in this book is prohibited except with permission in writing from the publisher. The CCC fee code is 0277-786X/16/\$18.00.

Printed in the United States of America.

Publication of record for individual papers is online in the SPIE Digital Library.

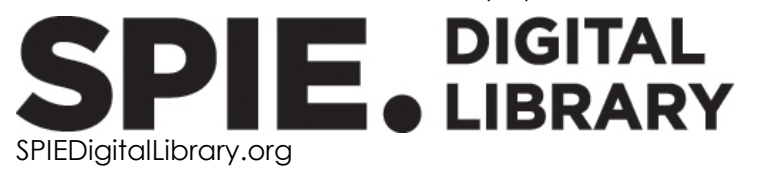

Paper Numbering: Proceedings of SPIE follow an e-First publication model. A unique citation identifier (CID) number is assigned to each article at the time of publication. Utilization of CIDs allows articles to be fully citable as soon as they are published online, and connects the same identifier to all online and print versions of the publication. SPIE uses a six-digit CID article numbering system structured as follows:

- The first four digits correspond to the SPIE volume number.

- The last two digits indicate publication order within the volume using a Base 36 numbering system employing both numerals and letters. These two-number sets start with 00, 01, 02, 03, 04, $05,06,07,08,09,0 A, 0 B \ldots$ OZ, followed by 10-1Z, 20-2Z, etc. The CID Number appears on each page of the manuscript. 


\title{
Contents
}

\author{
$\checkmark$ Authors \\ vii Conference Committee
}

WIDE BAND GAP MATERIALS AND DEVICES I

995703 Evaluation of surface recombination of SiC for development of bipolar devices (Invited Paper) [9957-2]

995704 Influence of hydrogen plasma irradiation on defects of ZnO [9957-3]

WIDE BAND GAP MATERIAL AND DEVICES II

$995709 \mathrm{Ga}_{2} \mathrm{O}_{3}$ as both gate dielectric and surface passivation via sol-gel method at room ambient [9957-8]

\section{WBG POWER APPLICATIONS I}

9957 OA A survey on GaN- based devices for terahertz photonics (Invited Paper) [9957-9]

9957 OC Switching performance and efficiency investigation of GaN based DC-DC Buck converter for low voltage and high current applications [9957-11]

\section{POSTER SESSION}

$9957 \mathrm{OH} \quad$ Simulation of push-pull inverter using wide bandgap devices [9957-16]

9957 Ol Silicon carbide DC-DC multilevel Cuk converter [9957-17]

9957 OJ Modeling a multilevel boost converter using SiC components for PV application [9957-18]

9957 OK Performance evaluation of a high power DC-DC boost converter for PV applications using SiC power devices [9957-19]

9957 OL Thermal modeling of wide bandgap materials for power MOSFETs [9957-20] 
Proc. of SPIE Vol. $9957995701-4$

Downloaded From: https://www.spiedigitallibrary.org/conference-proceedings-of-spie on 25 Apr 2023 Terms of Use: https://www.spiedigitallibrary.org/terms-of-use 


\title{
Authors
}

Numbers in the index correspond to the last two digits of the six-digit citation identifier (CID) article numbering system used in Proceedings of SPIE. The first four digits reflect the volume number. Base 36 numbering is employed for the last two digits and indicates the order of articles within the volume. Numbers start with 00, 01, 02, 03, 04, 05, 06, 07, 08, 09, 0A, 0B...0Z, followed by 10-1Z, 20-2Z, etc.

\author{
Abe, Koji, 04 \\ Ahi, Kiarash, OA \\ Alatawi, Khaled S., OC, OK \\ Alateeq, Ayoob S., Ol, OJ \\ Al-badri, Mustafa, $\mathrm{OH}$ \\ Almalaq, Yasser A., Ol, $0 \mathrm{~J}$ \\ Almasoudi, Fahad M., OC, OK \\ Anwar, Mehdi, OA \\ Cansızoglu, Hilal, 09 \\ Chowdhury, Srabanti, 09 \\ Gao, Jianyi, 09 \\ GhandiParsi, Soroush, 09 \\ Hata, Hiroki, 04 \\ Islam, M. Saif, 09 \\ Kato, Masashi, 03 \\ Kaya, Ahmet, 09 \\ Mamtaz, Hasina H., 09 \\ Manandhar, Mahesh B., OL \\ Matin, Mohammed A., OC, OH, OI, OJ, OK, OL \\ Mayet, Ahmed S., 09
}

Proc. of SPIE Vol. $9957995701-5$ 
Proc. of SPIE Vol. $9957995701-6$

Downloaded From: https://www.spiedigitallibrary.org/conference-proceedings-of-spie on 25 Apr 2023 Terms of Use: https://www.spiedigitallibrary.org/terms-of-use 


\section{Conference Committee}

Program Track Chairs

Shizhuo Yin, The Pennsylvania State University (United States)

Ruyan Guo, The University of Texas as San Antonio (United States)

Conference Chairs

Mohammad Matin, University of Denver (United States)

Abdul A. S. Awwal, Lawrence Livermore National Laboratory (United States)

Achyut K. Dutta, Banpil Photonics, Inc. (United States)

Conference Program Committee

Srabanti Chowdhury, University of California, Davis (United States)

M. Saif Islam, University of California, Davis (United States)

Mowafak M. Al-Jassim, National Renewable Energy Laboratory (United States)

Hidenori Mimura, Shizuoka University (Japan)

Rebecca J. Nikolic, Lawrence Livermore National Laboratory (United States)

Madan Niraula, Nagoya Institute of Technology (Japan)

Bart Van Zeghbroeck, University of Colorado at Boulder (United States)

Session Chairs

1 Wide Band Gap Materials and Devices I

Achyut K. Dutta, Banpil Photonics, Inc. (United States)

2 Wide Band Gap Material and Devices II

Mohammad Matin, University of Denver (United States)

3 WBG Power Applications I

Srabanti Chowdhury, University of California, Davis (United States)

4 WBG Power Applications II

M. Saif Islam, University of California, Davis (United States) 
Proc. of SPIE Vol. $9957995701-8$

Downloaded From: https://www.spiedigitallibrary.org/conference-proceedings-of-spie on 25 Apr 2023 Terms of Use: https://www.spiedigitallibrary.org/terms-of-use 